\title{
Capitalization as a Tool for Managing the Development of Industry and Rail Transport
}

\author{
Igor Posokhov ${ }^{1 *}$, Victoriia Cherepanova ${ }^{1}$, Olha Podrez ${ }^{1}$ \\ 1 National Technical University "Kharkiv Polytechnical Institute", Chair of Innovative \\ Entrepreneurship Management and International Economic Relations, Kirpichova str. 2. Kharkiv, \\ 61002 Ukraine
}

\begin{abstract}
The Ukrainian real economy encounters similar problems that do not allow its rapid development - high level of wear of productive assets, lack of modern equipment, outdated technologies, inappropriate environmental measures, high rate of occupational injury, etc. All this requires designing of new tools to manage the development of such important sectors of economy as industry and rail transport. Therefore, the urgent issues at the current stage of development of these industries include the definition of conditions for fixed assets capitalization and the sources of its financing. The scientific novelty of the results is identification and justification of the capitalization main components, determining the sources of funding and the mechanism for their attraction. The tool for managing the productive and environmental protection assets capitalization has been designed which is optimized using a twodimensional dynamic programming model. The results obtained are the basis for the practical solution of the problem, and for further scientific research. This approach allows solving the problem of rail transport and industrial enterprises capitalization in a comprehensive manner, which contributes to their sustainable development.
\end{abstract}

\section{Introduction}

Many countries of the world that are gradually overcoming the financial recession and whose objective is strong economic growth and enhancing quality of life, have same global problems: industry recovery, the introduction of innovative technologies in production and environmental protection, the provision of rail transport to supply raw materials, and final products marketing. Therefore, the issue of industrial facilities and rail transport development should be resolved in parallel. This is, especially, case of capitalization, which J. M. Keynes [1] describes as a "method of capital accumulation, one part of which is consumed, while the other is invested in long-term production and investment assets".

\footnotetext{
${ }^{*}$ Corresponding author: posokhov7@gmail.com
} 
The importance of these two sectors of capitalization is confirmed by the fact that Ukrzaliznytsia has the old rolling stock fleet and infrastructure (51.7\%) [2], while productive assets wear of industrial enterprises is over $60 \%$, and in some cases, over $80 \%$.

Taking into account the urgency of the problem, the main purpose of this study is to characterize the state of capital investments in the industrial enterprises fixed assets (for example, coking plants) and rail transport and to develop a tool for managing the enterprises development in capitalization conditions. To achieve these objectives, we have specified the following tasks:

-developing the conceptual construct of "capitalization" category;

-indicating general lines and financial sources of the enterprises capitalization;

-proposing the structure of managerial tool for the enterprises development in capitalization conditions.

\section{Literature review}

In the economic literature, the notion of "capitalization" has been used for a long time and differently. We propose to consider this term based on scientific approaches.

Karl Marx [3] wrote that capitalization is a "process of turning a part of profit (income) or total profit (income) into additional capital and factors of production (plant and machinery, material and supplies, manpower, etc.) and using it to expand production". Unlike K. Marx, S.V. Mocherny [4] complements his production approach with financial one - "the investment of part of the income into securities to receive profit from them in the form of interest". V.G. Zolotogorov [5] states that this term relates to the "estimation of an enterprise value", i.e., a cost approach is used, while R. Koch [6], M. Bertonesh and R. Knight [7], I.P. Buleev and M. A. Solod [8], S. Raza [9] and A. Singal [10] specify that capitalization is "the market value of a company whose shares are quoted on a stock exchange" [6], thus combining cost, market and financial approaches. I.P. Buleeva and N.E. Bryukhovetska [11] consider the definition of "capitalization" by economy levels (enterprise, branch of industry, region, national economy, international economy) and insist on production market approach to its conceptual framework. [11].

M.A. Kozoriz [12], V.M. Geits and A.A. Gritsenko [13] insist on a broader approach to the term "capitalization" which would cover different levels, spheres and the management mechanism with respect to production-financial approach.

Based on the generalization of the existing approaches to the concept of 'capitalization', we define this term as an economic category whose actions are aimed at obtaining additional capital to create productive assets in order to increase revenues from the sale of products and services in conditions of environmental safety of production.

The category of "capitalization" has a wide range of applications, such as production, financial, market-based, institutional; it is used at all levels of government - state (macro), industry branch-based (meso-) and entrepreneurial (micro level) and spheres of economy processing industry, agriculture, transport, financial and credit system, etc.; it has its own management mechanism, which includes the appropriate tools. In this case, it relates to fixed assets, intangible assets, material resources.

\section{Problem description and methodology}

The problems of Ukrzaliznytsia and coking plants functioning are associated with outdated fixed assets and low environmental protection of the production process and services rendering. Thus, as of 01.01.19, the total number of coke batteries of the Ukrainian Research and Industrial Association (URIA) Ukrkoks [14] decreased by 17 pcs. vs. 1.01.14, the average age of the batteries is 29.07 years while the norm is 20 years, that is, $66.7 \%$ of 
the batteries are outdated, and there are 8 batteries with an operating life exceeding 35 years.

URIA Ukrkoks solves the coke batteries problem by investing its own funds into the KHP assets (Fig. 1). During the period from 2013 to 2018, capital investments of KHP increased twice from UAH 421,215 thousand in 2013 to UAH 958,940 thousand in 2018. Starting from 2015, the cost of major repairs exceeds the cost of acquiring and creating assets. The costs for equipment reconstruction and upgrading equal only to $24.56 \%$ of the total capital investment amount [14].

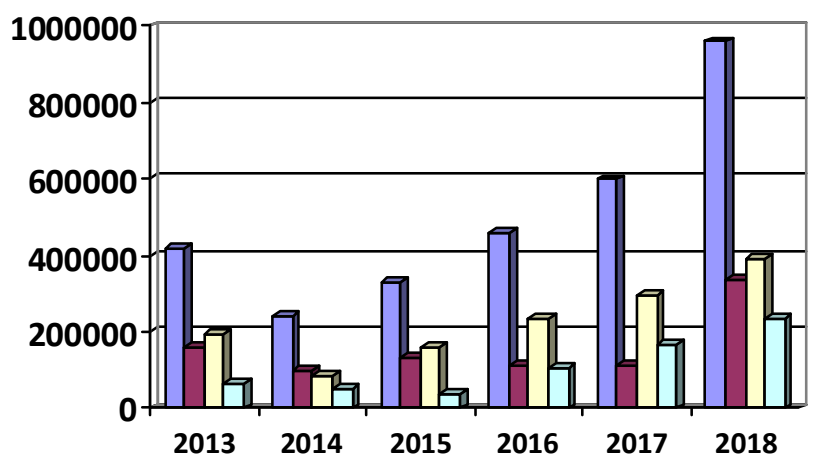

\begin{tabular}{|l|}
\hline Amount of capital \\
investment assimilated in \\
the reporting period \\
$\square$ Costs for assets purchase \\
and creation \\
$\square$ Costs for major repair \\
$\square$ Costs for reconstruction, \\
modernization
\end{tabular}

Fig. 1. Dynamics of KHP capital investments, thou. UAH [14].

All capital investments were made at the expense of the company's own funds.

A similar situation is observed in Ukrzaliznytsya. According to Ukrzaliznytsya, JSC financial reporting [15], the fixed assets depreciation is $60 \%$, which is 0.9 of that in 2017 . In the two last years, Ukrzaliznytsia's capital investments grew 1.55 times. Ukrzaliznytsya JSC pays the major attention to the construction of new objects of fixed assets, modernization and repair of the old ones. To renew the rolling stock, regional branches, branch offices allocated by 1.5 times more funds than in 2017, performed 4,282,7 million UAH worth capital construction works, acquired mechanisms and equipment, and other noncurrent tangible and intangible assets by 1.3 times more than in the previous year.

Thus, the by-product coking industry and Ukrzaliznytsya are upgrading, repairing and modernizing the main productive assets (MPA), but Ukrzaliznytsa has paid more attention to capital construction in these recent years, while KHP - to the capital repairs.

Issues of capitalization of production are directly related to the availability of financial sources (Table 1).

Increased capital investments of Ukrzaliznytsya JSC in 2018 were mainly funded with its own funds and attracted credit resources, which increased 2.73 times this year [15]. Ukrzaliznytsya and coking plants have another feature in common - the negative impact on the environment caused by their activities. Emission volumes depend on coke production and on measures implemented by KHP at their enterprises and capital investments allocated to environmental protection. Environmental expenditures of URIA Ukrkoks were allocated to capital investments, including major repairs, and current investments.

Table 1. Analysis of Ukrzaliznytsya JSC sources of financing of capital investments for the period from 2017 to 2018 [15].

\begin{tabular}{|c|c|c|c|c|}
\hline Sources of financing & 2017 & 2018 & $\begin{array}{c}\text { Absolute } \\
\text { deviation }\end{array}$ & $\begin{array}{c}\text { Accretion, } \\
\%\end{array}$ \\
\hline
\end{tabular}




\begin{tabular}{|c|c|c|c|c|}
\hline $\begin{array}{c}\text { Capital investment sources, } \\
\text { total, including: }\end{array}$ & $10,904,079$ & $16,912,841$ & 6008762 & 55.1 \\
\hline contracted loans & 538,844 & $2,012,476$ & 1473632 & 273 \\
\hline Budget funding & - & - & - & - \\
\hline Own costs & $10,337,225$ & $14,860,811$ & 4523586 & 43.76 \\
\hline Other sources & 28,010 & 39,554 & 11544 & 41.21 \\
\hline
\end{tabular}

In the cost structure, the largest share was borne by current expenditures in 2017-2018, which in 2018 decreased by $9 \%$, and the cost of major repairs increased by $56.3 \%$. [14].

A similar situation is observed in Ukrzaliznytsya JSC In the freight transportation performed in 2018, the largest share, by hazard class [15], belongs to class 3 (easycombustible fluids) $-47 \%$.

Thus, issues of capitalization of fixed assets are relevant for both the industry and Ukrzaliznytsia.

The methodological basis of this article is the design of a tool for managing production capitalization with respect to fixed assets, which consists of three management levels:

1. Production technical, through which the choice of fixed assets is made for production by type of improvement - purchase or new assets construction, major repairs, modernization (reconstruction);

2. Production environmental - the choice of the fixed environmental assets by type of improvement is made - purchase or construction of new assets, major repairs, current disposal measures and reverse water supply;

3. Financial investment - justification of the amount of capital investments is made by two levels of management and sources of their financing - own, contracted attracted loans, budget funds and other sources;

4. Organizational optimization - a model of dynamic programming is structured which takes into account: replacement of equipment (industrial and environmental), time of capital repairs according to schedule of planned production repairs and types of funds improvement (purchase or construction, major repairs, modernization (reconstruction) or current measures.

\section{Findings}

Fig. 2 provides the structure of fixed assets capitalization management of the industrial enterprise by management levels.

I.V. Kryvovyazyuk [16] emphasizes necessity of dynamic programming in the process of production facility capitalization. However, in our case, economic mathematical model of the dynamic issue is a two-dimensional investment resources allocation model [16] for productive and environmental assets. 
The tool for capitalization management of a production facility

\begin{tabular}{|c|c|c|c|c|}
\hline \multicolumn{2}{|l|}{$\nabla$} & \multicolumn{3}{|c|}{$\downarrow$} \\
\hline \multicolumn{2}{|c|}{$\begin{array}{l}\text { 1. Production technical } \\
\text { management level }\end{array}$} & \multicolumn{3}{|c|}{$\begin{array}{l}\text { 2. Production environmental } \\
\text { management level }\end{array}$} \\
\hline \multirow{2}{*}{$\begin{array}{l}\text { Construction } \\
\text { of basic } \\
\text { production }\end{array}$} & \multirow{2}{*}{$\begin{array}{l}\text { Consequenc } \\
\text { es: } \\
\text { emissions }\end{array}$} & \multicolumn{2}{|c|}{$\begin{array}{l}\text { New environmenta } \\
\text { funds }\end{array}$} & $\begin{array}{l}\text { Consequenc } \\
\text { es: costs }\end{array}$ \\
\hline & & \multicolumn{3}{|c|}{ Result: decrease in emissions } \\
\hline \multicolumn{2}{|c|}{$\begin{array}{l}\text { Result: growth of production } \\
\text { capacity }\end{array}$} & \multicolumn{2}{|c|}{$\begin{array}{l}\text { Major repair of } \\
\text { env. assets }\end{array}$} & $\begin{array}{l}\text { Consequenc } \\
\text { es: costs }\end{array}$ \\
\hline $\begin{array}{l}\text { Repair of } \\
\text { MPA }\end{array}$ & $\begin{array}{l}\text { Consequences: } \\
\text { missions }\end{array}$ & \multicolumn{3}{|c|}{$\begin{array}{l}\text { Result: reductions in emissions } \\
\text { and env. expenditures }\end{array}$} \\
\hline \multicolumn{2}{|c|}{ Result: increase in the output } & \multirow{2}{*}{$\begin{array}{l}\text { Current } \\
\text { measures }\end{array}$} & \multirow{2}{*}{\multicolumn{2}{|c|}{$\begin{array}{l}\text { Consequences: } \\
\text { costs }\end{array}$}} \\
\hline \multirow{2}{*}{$\begin{array}{l}\text { Modernizati } \\
\text { on of } \\
\text { MPA }\end{array}$} & \multirow{2}{*}{$\begin{array}{l}\text { Consequences: } \\
\text { emissions }\end{array}$} & & & \\
\hline & & \multicolumn{3}{|c|}{ Result: primary energy saving } \\
\hline \multicolumn{2}{|c|}{$\begin{array}{l}\text { Result: products quality } \\
\text { improvement }\end{array}$} & \multicolumn{3}{|c|}{$\begin{array}{l}\text { 4. Financial-optimization } \\
\text { management level }\end{array}$} \\
\hline \multicolumn{2}{|c|}{$\begin{array}{l}\text { 3. Financial-investment } \\
\text { management level }\end{array}$} & \multicolumn{3}{|c|}{ Dynamic programming } \\
\hline \multicolumn{2}{|c|}{$\begin{array}{l}\text { Own sources, contracted } \\
\text { loans. budget costs. other }\end{array}$} & & & \\
\hline
\end{tabular}

Fig. 2. The tool for managing production facility capitalization (developed by the authors).

\section{Conclusions}

Capitalization of production is important for the industry and Ukrzaliznytsia. It requires making managerial decisions regarding the improvement of productive and environmental fixed assets (purchase of new assets, major repair old assets, modernization, reconstruction and current measures), optimal allocation of investment resources in order to obtain the maximum income by the enterprise from the production and sale of products (services) and reduction in environmental payments due to emission reductions.

We propose to resolve this problem by constructing a managerial tool for capitalization of production in relation to fixed assets, which consists of four management levels: production and technical, production and environmental, financial and investment and organizational and optimization. With the help of the first one, the justification of the choice of the fixed production assets as to the lines of their improvement, the second one the main means of environmental protection, the third one - the amounts of necessary investments and financial sources for its coverage, and the fourth one - the allocation of capital investments between the fixed production funds and the environmental protection 
assets. The optimization of funds allocation is proposed to be carried out by a twodimensional dynamic programming model, which allows to maximize income of the enterprise due to replacement of fixed assets and to receive income from increased output and reduction in environmental expenditure by emissions reduction.

The research results can be used both by industrial enterprises and Ukrzaliznytsya.

\section{References}

1. J. M. Keynes, The general theory of employment, interest and money. Favorites, Moscow (2007).

2. Purposes of the Sustainable Development Goals: Ukraine. The Ministry of Ukraine's economic development and trade, Kiev (2017).

3. K. Marx, Capital: Critics of political economics. - T. 2. - Kn. II: Capital circuit process, Moscow (1974).

4. Economic encyclopaedia: in 3 vol. [edited by S. V. Mocherny]., Kiev (2000).

5. V.G. Zolotogorov Economics: encyclopaedic dictionary, Minsk (2004).

6. R. Koch, Management and Finance from A to Z., St. Petersburg (1999).

7. M. Bertonesh, R. Knight Money, Flow Management, (St. Petersburg) (2004).

8. I.P. Buleev, M.A Solod, Problems of capitalization of metallurgical enterprises In modern conditions. Economy of Industry, 1 (73), 73-82 (2016).

9. S.Raza, T. Jawaid, S. Afshan, M. Ka-rim, Is stock market sensitive to foreign capital inflows and economic growth? Evidence from Pakistan Journal of Chinese Economic and Foreign Trade Studies. 8 (3), 142-164 (2015) https://doi.org/10.1108/JCEFTS03-2015-0012

10. A. Singal, A. Jain, Emerging market firms: measuring their success with strategic positioning maps. Journal of Business Strategy. 35 (1), 20-28 (2014).

https://doi.org/10.1108/JBS-04-2013-0026

11. Capitalization of enterprises: theory and practice: monograph / edited by I.P. Buleeva, N.E. Bryukhovetska, NAN of Ukraine, Institute of industrial economy, Donetsk (2011).

12. M.A. Kozoriz, Capitalization role and function in ensuring economic development of economic entities. Regional economics, 2, 42-48 (2007).

13. Capitalization of Ukrainian economy / edited by acad. of NAN of Ukraine V.M. Geits, A.A. Grizenko. Institute of Economics and Forecasting of NAN Ukraine, Kiev (2007).

14. Ukrainian Scientific-Industrial Association "Ukrkoks": Results of the work of cokechemical enterprises and industries of Ukraine in 2018, Dnepr (2019).

15. Consolidated financial plan of Ukrzaliznytsia JSC, [online], Available at: https://www.uz.gov.ua/about/investors/financial_statements/kfp/

16. A.M. Romanovskaya, M.V. Mendziv, Dynamic programming: Handbook, Omsk (2010). 